Eur. J. Clin. Chem. Clin. Biochem.

Vol. 32, 1994, pp. 71-77

(c) 1994 Walter de Gruyter \& Co. Berlin - New York

\title{
Age Dependent Reference Intervals of Glucose, Urea, Protein, Lactate and Electrolytes in Thermally Induced Sweat ${ }^{1}$
}

\author{
By Y. Y. Al-Tamer and E. A. Hadi \\ Department of Chemistry, College of Education, University of Mosul, Iraq
}

(Received February 9/November 9, 1993)

Summary: Concentrations of electrolytes, lactate, urea, glucose, total lipids and total protein were measured in sweat obtained by thermal stimulation of apparently healthy volunteers. Blood and urine samples were also collected. Electrolytes, urea and total protein were also measured in serum. The concentrations of electrolytes, glucose and urea in sweat increased with age, and this increase was more apparent in males, probably due to certain agerelated changes in male sweat glands. The concentrations of lactate, total protein and total lipids in sweat, however, were not age-dependent. The concentration of total protein was higher in females than in males. The concentrations of all the other analytes were higher in males than in females of the same age group.

\section{Introduction}

Sweat is a dilute electrolyte solution containing small amounts of other constituents. Its primary physiological function, as far as is known, is the control of body temperature (1).

Although the total amount of sweat produced at any time over the whole body surface may be large, particularly during exercise, the local amount is usually small. One problem in studying sweat is sample collection (2).

There are two types of sweat:

eccrine, produced by eccrine cells on most of the body surface and stimulated by cholinergic fibres present in sympathetic nerves, and

apocrine, produced by apocrine cells developed from hair follicles and located mainly in the axilla and pubic areas, whose secretion is stimulated by adrenaline (3).

The eccrine sweat gland consists of a secretory coil and a duct. The secretory coil produces primary secretion.

\footnotetext{
1) This work is part of the M. Sc. thesis of Eman Adil Hadi pre-
} sented to Mosul University.
Its composition is very similar to that of plasma except for protein. It contains high concentrations of $\mathrm{Na}^{+}$and $\mathrm{Cl}^{-}$but much smaller concentrations of other solutes. As this fluid passes through the duct, most of the $\mathrm{Na}^{+}$ and $\mathrm{Cl}^{-}$is reabsorbed, reducing the osmotic pressure so that most of the water is reabsorbed. This process concentrates most of the other constituents (4).

The normal unacclimatized subject produces about 700 $\mathrm{ml}$ of sweat every hour when exposed to hot weather for 1-6 weeks. This amount increases to $1500 \mathrm{ml}$ hourly when the subject is exposed for longer periods. Evaporation of the fluid removes body heat at a rate 10 times higher than the basal rate. With acclimatization the $\mathrm{NaCl}$ concentration of the sweat decreases, so that $\mathrm{NaCl}$ is conserved. This effect is largely due to aldosterone secretion (4). In addition to hot climatic conditions, sweating is also induced by emotional state, exercise, fainting, vomiting and gustatory factors (5).

This work was initiated to obtain more information about the chemical composition of eccrine sweat fluid and its relationship with age. In our opinion, this may provide useful, clinically relevant information, particularly in diabetic and uraemic cases. 


\section{Materials and Methods}

\section{Subjects}

The voluntcers were apparently healthy subjects (not suffering from cystic fibrosis, diabetes or uraemia). None of them was under treatment. They were all residents of Mosul city.

The volunteers were divided into five age groups of both sexes as follows:

\begin{tabular}{lll}
\hline $\begin{array}{l}\text { Group } \\
\text { No. }\end{array}$ & $\begin{array}{l}\text { Age } \\
\text { (a) }\end{array}$ & $\mathrm{n}$ \\
\hline 1 & $6-15$ & 14 \\
2 & $16-25$ & 26 \\
3 & $26-35$ & 19 \\
4 & $36-45$ & 16 \\
5 & $46-55$ & 11 \\
\hline
\end{tabular}

\section{Sample collection}

The facial area was thoroughly cleaned with water and dried immediately before starting the experiment. The subjects were allowed to stay in ambient temperature ranging from $40=45^{\circ} \mathrm{C}$ (which is the normal day temperature during the Iraqi summer months).

After 2-3 minutes, drops of sweat accumulated on the skin of the subjects and were immediately withdrawn with a syringe; $10-15$ $\mathrm{ml}$ of sweat were collected in this way. Samples were then divided into 3-4 portions and kept in thoroughly washed capped glass tubes (rinsed several times with distilled water and dried). They were then kept frozen at $-20^{\circ} \mathrm{C}$ for not more than 30 days before analysis.

Blood samples $(5 \mathrm{ml})$ were withdrawn, and serum samples were separated and stored in capped tubes at $-20^{\circ} \mathrm{C}$ for not more than 15 days before analysis.

Urine samples were obtained at the time of sweat collection, kept in clean plastic containers and used immediately.

Chemicals and reagents were obtained from Fluka Chemie AG, CH 9470 Buchs, Switzerland, or BDH Limited, Poole, England.

\section{Methods}

The $\mathrm{Na}^{+}$and $\mathrm{K}^{+}$concentrations of sweat and serum were measured by flame photometry (5) and $\mathrm{Cl}^{-}$concentration by a spectro- photometric method (hexachloroferrate complex at $348 \mathrm{~nm}$ ) (6). Sweat lactate concentrations were measured by an enzymatic method (7). Serum and sweat urea concentrations were determined by the diacetyl monoxime method (5). Sweat glucose was measured by a modified Harding method $(7,8)$ and total protein by the Lowry method (9). Total plasma protein was measured by the Biuret method (10). Total lipids were determined by the phosphovanillin spectrophotometric method (5).

is

Urine samples were tested for albumin by the acetic acid method (11) and for sugar by using test strips (Ëli Lilly and Company, Indianapolis, IN 46285, U. S. A.).

The Wilcoxon rank-sum test of statistical analysis was used throughout the study.

Pooled human serum was used as a quality control sample. The coefficient of variation wạs less than $5 \%$ for all tested quantities, except lactate which showed a CV of $10 \%$. For most studied analytes the amount of swèat collected was sufficient. However, the lactate determination required a large quantity of sweat fluid and for some subjects the amount available was not sufficient. In some groups, a smaller number of samples was therefore analysed for lactate.

\section{Results}

\section{Concentrations of electrolytes}

The serum concentration of electrolytes was similar in all groups, and there were no significant differences among the various age groups or between males and females. The concentrations of electrolytes in sweat are shown in table 1 for $\mathrm{Na}^{+}$, table 2 for $\mathrm{K}^{+}$and table 3 for $\mathrm{Cl}^{-}$.

These tables show that electrolyte concentrations in sweat fluid increase with age. This increment was more apparent in males. In the same age group the electrolyte concentration in males was higher than in females.

The relationship between the concentrations of electrolytes was demonstrated in sweat obtained after pilocarpin stimulation (12); in every age group $\mathrm{Na}^{+}$was higher

Tab. 1 Concentration of $\mathrm{Na}^{+}(\mathrm{mmol} / \mathrm{l})$ in sweat fluid.

\begin{tabular}{|c|c|c|c|c|c|}
\hline Age (a) & $6-15$ & $16-25$ & $26-35$ & $36-45$ & $46-55$ \\
\hline \multirow[t]{2}{*}{$\begin{array}{l}\text { Males } \\
\mathrm{n} \\
\text { Median } \\
\text { Range }\end{array}$} & $\begin{array}{l}12 \\
57.8 \\
43.5-105.4\end{array}$ & $\begin{array}{l}18 \\
82.3 \\
62.2-113\end{array}$ & $\begin{array}{l}9 \\
91.7 \\
75.2-118.7\end{array}$ & $\begin{array}{l}7 \\
101 \\
74.8-135.6\end{array}$ & $\begin{array}{l}8 \\
116 \\
65.2-146\end{array}$ \\
\hline & $\Rightarrow$ III & $\Leftrightarrow$ & NS $\Leftrightarrow$ & $\mathrm{NS} \Leftrightarrow$ & $\mathrm{NS} \Leftarrow$ \\
\hline \multirow[t]{2}{*}{$\begin{array}{l}\text { Females } \\
\mathrm{n} \\
\text { Median } \\
\text { Range }\end{array}$} & $\begin{array}{l}8 \\
60 \\
38.5-101.6\end{array}$ & $\begin{array}{l}3 \\
94 \\
77-94\end{array}$ & $\begin{array}{l}5 \\
88 \\
83-98\end{array}$ & $\begin{array}{l}6 \\
88.5 \\
78.5-97\end{array}$ & $\begin{array}{l}4 \\
102.6 \\
92.3-109\end{array}$ \\
\hline & $\Rightarrow \mathrm{NS}$ & $\Leftrightarrow$ & NS $\Leftrightarrow$ & $\mathrm{NS} \Leftrightarrow$ & $\mathrm{NS} \Leftarrow$ \\
\hline $\begin{array}{ll}\text { Range } & = \\
\mathrm{n} & = \\
\mathrm{NS} & =\end{array}$ & $\begin{array}{l}=2.5-97.5 \text { percentiles } \\
=\text { number of samples collected } \\
=\text { not significant }\end{array}$ & $\begin{array}{l}\text { Statistical sign } \\
\mathrm{I}, \alpha<0.1 \text {; II, }\end{array}$ & $\begin{array}{l}\text { ween groups } \\
\text { III, } \alpha<0.02 \text {; }\end{array}$ & .002 & \\
\hline
\end{tabular}


Tab. 2 Concentration of $\mathrm{K}^{+}(\mathrm{mmol} / \mathrm{l})$ in sweat fluid.

\begin{tabular}{|c|c|c|c|c|c|}
\hline Age (a) & $6-15$ & $15-25$ & $26-35$ & $36-45$ & $46-55$ \\
\hline \multirow[t]{2}{*}{$\begin{array}{l}\text { Males } \\
\mathrm{n} \\
\text { Median } \\
\text { Range }\end{array}$} & $\begin{array}{l}12 \\
16.9 \\
11.4-23.2\end{array}$ & $\begin{array}{l}18 \\
27.1 \\
13.5-40\end{array}$ & $\begin{array}{l}9 \\
33.6 \\
22-43.6\end{array}$ & $\begin{array}{l}7 \\
37.6 \\
28.2-44.8\end{array}$ & $\begin{array}{l}8 \\
38 \\
32.8-40\end{array}$ \\
\hline & $\Rightarrow \mathrm{IV}$ & $\Leftrightarrow$ & NS $\Leftrightarrow$ & NS $\Leftrightarrow$ & $\mathrm{NS} \Leftarrow$ \\
\hline \multirow[t]{2}{*}{$\begin{array}{l}\text { Females } \\
\mathrm{n} \\
\text { Median } \\
\text { Range }\end{array}$} & $\begin{array}{l}8 \\
11.1 \\
10.7-13.6\end{array}$ & $\begin{array}{l}4 \\
23.4 \\
18.8-28.2\end{array}$ & $\begin{array}{l}3 \\
22.3 \\
20-28.8\end{array}$ & $\begin{array}{l}5 \\
20.7 \\
16.3-33\end{array}$ & $\begin{array}{l}4 \\
24 \\
23-25.2\end{array}$ \\
\hline & $\Rightarrow \mathrm{NS}$ & $\Leftrightarrow$ & NS $\Leftrightarrow$ & NS $\Leftrightarrow$ & $\mathrm{NS} \Leftarrow$ \\
\hline
\end{tabular}

Range $=2.5-97.5$ percentiles

$\mathrm{n}=$ number of samples collected

Statistical significance between groups

NS $=$ not significant

I, $\alpha<0.1$; II, $\alpha<0.05$; III, $\alpha<0.02$; IV, $\alpha<0.002$

Tab. 3 Concentration of $\mathrm{Cl}^{-}(\mathrm{mmol} / \mathrm{l})$ in sweat fluid.

\begin{tabular}{|c|c|c|c|c|c|}
\hline Age (a) & $6-15$ & $16-25$ & $26-35$ & $36-45$ & $46-55$ \\
\hline \multirow[t]{2}{*}{$\begin{array}{l}\text { Males } \\
\mathrm{n} \\
\text { Median } \\
\text { Range }\end{array}$} & $\begin{array}{l}12 \\
50.6 \\
41-100.4\end{array}$ & $\begin{array}{l}17 \\
94 \\
59.5-101\end{array}$ & $\begin{array}{l}9 \\
89.5 \\
71-102\end{array}$ & $\begin{array}{l}7 \\
94 \\
90.3-103\end{array}$ & $\begin{array}{l}6 \\
99.5 \\
96-107\end{array}$ \\
\hline & $\Rightarrow$ III & $\Leftrightarrow$ & NS $\Leftrightarrow$ & $\mathrm{NS} \Leftrightarrow$ & NS $\Leftarrow$ \\
\hline \multirow[t]{2}{*}{$\begin{array}{l}\text { Females } \\
\mathrm{n} \\
\text { Median } \\
\text { Range }\end{array}$} & $\begin{array}{l}7 \\
60 \\
41-102\end{array}$ & $\begin{array}{l}4 \\
87 \\
71-96\end{array}$ & $\begin{array}{l}5 \\
89 \\
74.5-100\end{array}$ & $\begin{array}{l}6 \\
84 \\
71-102\end{array}$ & $\begin{array}{l}5 \\
81.6 \\
74.5-108\end{array}$ \\
\hline & $\Rightarrow \mathrm{NS}$ & $\Leftrightarrow$ & $\mathrm{NS} \Leftrightarrow$ & NS $\Leftrightarrow$ & $\mathrm{NS} \Leftarrow$ \\
\hline
\end{tabular}

Range $=2.5-97.5$ percentiles

Statistical significance between groups

$\mathrm{n}=$ number of samples collected

NS $=$ not significant

I, $\alpha<0.1$; II, $\alpha<0.05$; III, $\alpha<0.02$; IV, $\alpha<0.002$

than $\mathrm{Cl}^{-}$by approximately $5 \mathrm{mmol} / \mathrm{l}$, and the ratio of $\mathrm{Na}^{+}$to $\mathrm{K}^{+}$was approximately $3: 1$.

Thes results agree with those of other authors using pilocarpine-stimulated sweat fluid $(13-15)$.

\section{Concentration of lactate}

It has been found that lactate concentration depends on the activity of sweat gland rather than on the age. As can be seen from table 4, the third age group exhibited the highest concentration. On the other hand, its concentration is rather low both in the first and fifth groups.

\section{Concentrations of urea and glucose}

The concentration of urea in serum was nearly the same in both sexes of all age groups.
The concentration of urea in sweat is shown in table 5 and the concentration of glucose in table 6 . These tables reveal that concentrations of urea and glucose in sweat increased with age, and this increase was more apparent in males. The concentration in males was higher than in the females of the same age group.

In sweat, the urea concentration was six or more times its serum level, while the glucose concentration was lower than its serum level.

\section{Concentrations of total protein and total lipids}

The concentration of total protein in serum was nearly the same in all age groups with no significant difference between males and females. 
Tab. 4 Concentration of lactate $(\mathrm{mmol} / \mathrm{l})$ in sweat fluid.

\begin{tabular}{|c|c|c|c|c|c|}
\hline Age (a) & $6-15$ & $16-25$ & $26-35$ & $36-45$ & $46-55$ \\
\hline \multirow[t]{2}{*}{$\begin{array}{l}\text { Males } \\
n \\
\text { Median } \\
\text { Range }\end{array}$} & $\begin{array}{l}5 \\
8.5 \\
5.3-10.8\end{array}$ & $\begin{array}{l}6 \\
16.6 \\
4.9-18.2\end{array}$ & $\begin{array}{l}4 \\
18.7 \\
18.3-18.9\end{array}$ & $\begin{array}{l}4 \\
16.5 \\
15.8-18.7\end{array}$ & $\begin{array}{l}4 \\
16 \\
15.5-17\end{array}$ \\
\hline & $\Rightarrow$ III & $\Leftrightarrow$ & III $\Leftrightarrow$ & $\mathrm{I} \Leftrightarrow$ & $\mathrm{NS} \Leftarrow$ \\
\hline \multirow[t]{2}{*}{$\begin{array}{l}\text { Females } \\
\mathrm{n} \\
\text { Median } \\
\text { Range }\end{array}$} & $\begin{array}{l}3 \\
6.2 \\
5.9-6.9\end{array}$ & $\begin{array}{l}3 \\
13.8 \\
13.5-14.6\end{array}$ & $\begin{array}{l}3 \\
15.1 \\
14.8-15.1\end{array}$ & $\begin{array}{l}3 \\
13.6 \\
13.3-14.3\end{array}$ & $\begin{array}{l}3 \\
11.5 \\
10.9-13\end{array}$ \\
\hline & $\Rightarrow$ II & $\Leftrightarrow$ & $\mathrm{I} \Leftrightarrow$ & II $\Leftrightarrow$ & $\dot{\mathrm{II}} \Leftarrow$ \\
\hline
\end{tabular}

Range $=2.5-97.5$ percentiles

Statistical significance between groups

$\mathrm{n} \quad=$ number of samples collected

I, $\alpha<0.1$; II, $\alpha<0.05$; III, $\alpha \dot{<} 0.02$; IV,$\alpha<0.002$

NS $=$ not significant

Tab. 5 Concentration of urea $(\mathrm{mmol} / \mathrm{l})$ in sweat fluid.

\begin{tabular}{|c|c|c|c|c|c|}
\hline Age (a) & $6-15$ & $16-25$ & $26-35$ & $36-45$ & $46-55$ \\
\hline \multicolumn{6}{|l|}{ Males } \\
\hline & 8 & 21 & 14 & 12 & 6 \\
\hline Median & 34.6 & 44.6 & 41.3 & 50 & 65.3 \\
\hline \multirow[t]{2}{*}{ Range } & $17-42.2$ & $17.1-75.6$ & $22.5-62.6$ & $40.4-66$ & $55.4-93.3$ \\
\hline & $\Rightarrow \mathrm{IV}$ & $\Leftrightarrow$ & NS $\Leftrightarrow$ & $\tilde{\mathrm{I}} \Leftrightarrow$ & $\dot{I I I I} \Leftarrow$ \\
\hline \multicolumn{6}{|l|}{ Females } \\
\hline $\mathrm{n}$ & 6 & 5 & 5 & 4 & 5 \\
\hline Median & 20.3 & 21.8 & 25.5 & 37.6 & 56.6 \\
\hline \multirow[t]{2}{*}{ Range } & $17-26.6$ & $20.6-23.1$ & $21.65-30.3$ & $34.8-40$ & $54.7-62$ \\
\hline & $\Rightarrow$ NS & $\Leftrightarrow$ & NS $\Leftrightarrow$ & II $\Leftrightarrow$ & $\mathrm{III} \Leftarrow$ \\
\hline
\end{tabular}

Range $=2.5-97.5$ percentiles

Statistical significance between groups

$\mathrm{n} \quad=$ number of samples collected $\quad \mathrm{I}, \alpha<0.1 ; \mathrm{II}, \alpha<0.05 ; \mathrm{III}, \alpha<0.02$; IV, $\alpha<0.002$

NS $=$ not significant

Tab. 6 Concentration of glucose $(\mathrm{mmol} / \mathrm{l})$ in sweat fluid.

\begin{tabular}{|c|c|c|c|c|c|}
\hline Age (a) & $6-15$ & $16-25$ & $26-35$ & $36-45$ & $46-55$ \\
\hline \multirow[t]{2}{*}{$\begin{array}{l}\text { Males } \\
\mathrm{n} \\
\text { Median } \\
\text { Range }\end{array}$} & $\begin{array}{l}13 \\
0.58 \\
0.1-1.22 \\
\end{array}$ & $\begin{array}{l}12 \\
1.18 \\
0.74-1.37\end{array}$ & $\begin{array}{l}9 \\
1.4 \\
0.85-3\end{array}$ & $\begin{array}{l}9 \\
1.9 \\
0.78-3.6\end{array}$ & $\begin{array}{l}6 \\
2.49 \\
2.27-3.9\end{array}$ \\
\hline & $\Rightarrow \mathrm{IV}$ & $\Leftrightarrow$ & NS $\Leftrightarrow$ & NS $\Leftrightarrow$ & $I \Leftarrow$ \\
\hline \multirow[t]{2}{*}{$\begin{array}{l}\text { Females } \\
\text { n } \\
\text { Median } \\
\text { Range }\end{array}$} & $\begin{array}{l}7 \\
0.39 \\
0.14-0.6\end{array}$ & $\begin{array}{l}5 \\
0.77 \\
0.6-1.35 \\
\end{array}$ & $\begin{array}{l}5 \\
0.95 \\
0.6-1.5 \\
\end{array}$ & $\begin{array}{l}4 \\
1.15 \\
0.47-1.5\end{array}$ & $\begin{array}{l}4 \\
1.45 \\
0.63-2\end{array}$ \\
\hline & $\Rightarrow$ III & $\Leftrightarrow$ & NS $\Leftrightarrow$ & NS $\Leftrightarrow$ & $\mathrm{NS} \Leftarrow$ \\
\hline
\end{tabular}

Range $=2.5-97.5$ percentiles

$\mathrm{n} \quad=$ number of samples collected

Statistical significance between groups

NS $=$ not significant

I, $<0.1 ;$ II, $>0.05 ;$ III, $<0.02 ;$ IV,$<0.002$ 
Tab. 7 Concentration of total lipids (mg/l) in sweat fluid.

\begin{tabular}{|c|c|c|c|c|c|}
\hline Age (a) & $6-15$ & $16-25$ & $26-35$ & $36-45$ & $46-55$ \\
\hline \multirow[t]{2}{*}{$\begin{array}{l}\text { Males } \\
\mathrm{n} \\
\text { Median } \\
\text { Rangc }\end{array}$} & $\begin{array}{l}11 \\
186 \\
115-317\end{array}$ & $\begin{array}{l}11 \\
324 \\
176-504\end{array}$ & $\begin{array}{c}8 \\
321 \\
246-403\end{array}$ & $\begin{array}{l}5 \\
312 \\
288-439\end{array}$ & $\begin{array}{l}\quad 7 \\
374 \\
268-657\end{array}$ \\
\hline & $\Rightarrow 1$ & $\Leftrightarrow$ & NS $\Leftrightarrow$ & NS $\Leftrightarrow$ & $\mathrm{NS} \Leftarrow$ \\
\hline \multirow[t]{2}{*}{$\begin{array}{l}\text { Females } \\
\text { n } \\
\text { Median } \\
\text { Range }\end{array}$} & $\begin{array}{c}7 \\
170 \\
117-309\end{array}$ & $\begin{array}{c}6 \\
188 \\
170-237\end{array}$ & $\begin{array}{c}9 \\
180 \\
167-360\end{array}$ & $\begin{array}{c}5 \\
257 \\
164-304\end{array}$ & $\begin{array}{c}5 \\
233 \\
172-299\end{array}$ \\
\hline & $\Rightarrow \mathrm{NS}$ & $\Leftrightarrow$ & NS $\Leftrightarrow$ & NS $\Leftrightarrow$ & $\mathrm{NS} \Leftarrow$ \\
\hline
\end{tabular}

Range $=2.5-97.5$ percentiles

Statistical significance between groups

$\mathrm{n} \quad=$ number of samples collected $\quad$ I, $\alpha<0.1$; II, $\alpha<0.05$; III, $\alpha<0.02$; IV, $\alpha<0.002$

NS $=$ not significant

The concentration of total lipids was higher in males than in females (see tab. 7), whereas the concentration of total protein (tab. 8) was higher in females than in males of the same age group. This is the only quantity that was higher in females than in males. However, total lipids and total protein show no relationship with age.

All tested samples of urine were clear and none showed the presence of albumin or glucose.

\section{Discussion}

Although sample collection was as quick as possible, evaporation cannot be ruled out. However, since this study concentrates mainly on comparing results from different age groups this point may not affect the general conclusion, but may be considered when comparing our results with those of others.

\section{Electrolytes concentrations}

It has been reported that aging affects the rate of $\mathrm{Na}^{+}$ excretion in sweat fluid (16). However, these results were clear in males but obscure in females.

In the present report, an age-related increase of $\mathrm{Na}^{+}$was apparent in both sexes, although the increase between successive age groups is not significant (tab. 1). On the other hand, if we compare the values of the first group (children) and the fifth group we see that they differ significantly $(\alpha<0.0001)$. This increase in $\mathrm{Na}^{+}$in sweat fluid with age may be attributed to one of the following factors:

a) Decrease of sodium resorption in the sweat gland duct $(16,27)$.

b) Increase of water resorption by the duct (18).

Tab. 8 Concentration of total protein (mg/l) in sweat fluid.

\begin{tabular}{|c|c|c|c|c|c|}
\hline Age (a) & $5-15$ & $16-25$ & $26-35$ & $36-45$ & $46-55$ \\
\hline \multirow[t]{2}{*}{$\begin{array}{l}\text { Males } \\
\mathrm{n} \\
\text { Median } \\
\text { Range }\end{array}$} & $\begin{array}{l}12 \\
150 \\
60-191\end{array}$ & $\begin{array}{l}13 \\
1 B 8 \\
78-138\end{array}$ & $\begin{array}{l}5 \\
125 \\
109-184\end{array}$ & $\begin{array}{c}9 \\
102 \\
72-187\end{array}$ & $\begin{array}{c}9 \\
119 \\
90-190\end{array}$ \\
\hline & $\Rightarrow I$ & $\Leftrightarrow$ & NS $\Leftrightarrow$ & NS $\Leftrightarrow$ & $\mathrm{NS} \Leftarrow$ \\
\hline \multirow[t]{2}{*}{$\begin{array}{l}\text { Females } \\
\mathrm{n} \\
\text { Median } \\
\text { Range }\end{array}$} & $\begin{array}{c}8 \\
151 \\
121-198\end{array}$ & $\begin{array}{c}6 \\
205 \\
188-265\end{array}$ & $\begin{array}{l}5 \\
202 \\
194-225\end{array}$ & $\begin{array}{c}6 \\
195 \\
168-225\end{array}$ & $\begin{array}{c}5 \\
193 \\
189-204\end{array}$ \\
\hline & $\Rightarrow$ IV & $\Leftrightarrow$ & NS $\Leftrightarrow$ & NS $\Leftrightarrow$ & $N S \Leftarrow$ \\
\hline
\end{tabular}

Range $=2.5-97.5$ percentiles

$\mathrm{n} \quad=$ number of samples collected

NS = not significant
Statistical significance between groups

I, $\alpha<0.1 ;$ II, $\alpha<0.05$; III, $\alpha<0.02 ; \alpha<0.002$ 
c) Decrease in the sensitivity of the sweat gland to aldosterone with age $(16,17)$.

This increase in $\mathrm{Na}^{+}$is followed by a concomitant increase in the $\mathrm{Cl}^{-}$concentration in the sweat fluid (12, 19).

Similiarly, the $\mathrm{K}^{+}$concentration in sweat fluid also increased with age. This increase is very apparent when comparing the first and fifth groups. The mechanism of $\mathrm{K}^{+}$excretion is somewhat different. It has been suggested that it may partially be due to secretion by the duct $(12,20)$ and increased $\mathrm{K}^{+}$permeability of the ductal wall, as well as increased negative potential (1).

The lower electrolyte concentration in females in all groups may be due to the higher serum aldosterone concentration in females (21). This causes an increase in the resorption of $\mathrm{Na}^{+}$in the duct, resulting in a lower concentration in sweat fluid.

\section{Lactate concentration}

Since lactate is the end product of carbohydrate metabolism in the sweat gland, the more active gland will produce more lactate. The much higher lactate concentration in sweat than in the corresponding serum (up to 8 times) supports the idea that lactate in sweat fluid comes primarily from the gland itself. The lower lactate concentration in the group of children (despite their high physical activity) is explained by their decreased sweating capacity, due to the decreased activity of their sweat glands $(12,22)$.

The older subjects may have reduced activity in general, and this is reflected in a lower concentration of sweat lactate. However, these speculations do not rule out other factors.

\section{Urea concentration}

It is known that the urea concentration of sweat fluid may be 4 times higher than its serum concentration, especially after exercise $(23,24)$. Our results showed that the urea concentration of sweat could even be as high as 6 or more times that of the serum.

In both sexes, the concentration of urea in sweat was more age-related than that of other quantitites. This high urea concentration and the weak linear relationship with its serum concentration leads us; to believe that the urea in sweat originates primarily from the gland itself, which would support previous findings (23). However a more speculative approach is that there may be a selective active excretion of urea in the sweat gland duct. This needs to be further elucidated.

The exact amount of urea excreted in sweat during the hot season is appreciable. The possible benefit of this for uraemic patients requires further investigation.

\section{Glucose concentration}

The glucose concentration of sweat fluid is lower than that of blood. Our findings support a previous report (25). However, our results show a gradual increase in sweat fluid glucose concentration with age in both sexes, and this was more apparent in males.

This age-related increase (though not always statistically significant) may be due to increasing permeability of the blood vessels during the formation of primary sweat fluid with age. Another possibility is that glucose transport across the membrane decreases with age, so that the quantity of glucose entering the cells of the sweat gland is decreased. This would lead to excessive availability of glucose and increased secretion into the sweat fluid.

Although the presence of glucose in sweat has been reported previously, the present work provides more detailed information. The occurrence of glucose in sweat could be studied further and may prove useful for diagnosis and follow-up of diabetic patients.

\section{Concentration of total lipids and total protein}

These two quantities show no significant relationship with aging. The concentrations of total protein are generally higher in females than in age-matched males.

\section{References}

1. Sato, K., Kang, W. H., Saga, K. \& Sato, K. T. (1989) Biology of sweat glands and their disorders. I - Normal sweat glands function. J. Am. Acad. Dermatol. 20, 537-563.

2. Bezegh, K., Bezegh, A., Black, P. G. \& Janata, J. (1988) Integrated probe for sweat analysis. J. Clin. Lab. Anal. 2, 16-18.

3. Keele, C. A. \& Nell, E. (1971) Samson Wright's Applied Physiology, $11^{\text {th }}$ ed. Oxford University Press, New York-Toronto, p. 336.

4. Heward, E. (1973) Text Book of Histology for Medical Student, $9^{\text {th }}$ ed. William Heinemann Medical Books, Ltd., London, pp. $481-482$.

5. Toro, G. \& Ackermann, P. G. (1975) Practical Clinical Chemistry, $1^{\text {st }}$ ed. Printed in the United States of America, pp. 271273, 143-145.

6. Snell, F. D. (1965) Photometric and Fluorometric Methods of Analysis of Nonmetals. John Wiley and Sons New YorkChichester, p. 250.

7. Varley, H. \& Gowenlock, A. H. (1980) Practical Clinical Biochemistry, $5^{\text {th }}$ ed. William Heinemann Medical Books Ltd. London, pp. 819-820, 397-398.

8. Plummer, D. T. (1978) Practical Biochemistry $2^{\text {nd }}$ ed. William Heinemann Medical Books Ltd., L. ondon, pp. 397-398. 
9. Lowry, O. H., Rosebrough, N. J., Farr, A. L. \& Randall, R. J. (1951) Protein measurement with the Folin phenol reagent. J. Biol. Chem. 193, 265-275.

10. Grandall, G. D. (1983) Biochemistry Laboratory. Oxford University Press, New York-Oxford, pp. 29, 83.

11. Bauer, J. D. \& Toro, G. (1968) Clinical Laboratory Methods, $7^{\text {th }}$ ed. C. V. Moisby Company, p. 18.

12. Fellmann, N., Labbe, A., Gachon, A. M. \& Coudert, J. (1985) Thermal sweat lactate in cystic fibrosis and in normal children. Eur. J. Appl. Physiol. 54, 511-516.

13. Lobeck, C. C. \& Mcsherry, N. R. (1963) Response of sweat electrolyte concentration to 9 alpha-fluorohydro-cortisone in patients with cystic fibrosis and their families. J. Pediatr. 62, 393-396.

14. Littlewood, J. M. (1986) The sweat test. Arch. Dis. Child. 61, 1041-1043.

15. Shwachman, H., Mahmoodian, A. \& Neff, R. K. (1981) The sweat test: Sodium and chloride values. J. Pediatr. 98, 576578.

16. Ohnishi, N., Ogawa, T., Sugenoya, J., Natsume, K., Yamashita, Y., Imamura, R. \& Yosef, K. (1989) Effect of aging on adaptability of sweating capacity in association with heat acclimatization. Thermal Physiol. 9, 475-480.

17. Ogawa, T. \& Ohnishi, N. (1989) Trainability of sweat glands in the aged. Biometeorology 7, 63-71.

18. Schulz, I. J. (1989) Micropuncture studies of the sweat formation in cystic fibrosis patients. J. Clin. Invest. 48, 1470-1477.
19. Shwachman, H. \& Mohmoodian, A. (1979) Quality of sweat test performance in the diagnosis of cystic fibrosis. Clin. Chem. 25, 158-161.

20. Sato, K. (1973) Sweat induction from an isolated eccrine sweat gland. Am. J. Physiol. 225, 1147-1152.

21. Tietz, N. W. (1986) Text Book of Clinical Chemistry. W. B. Saunders, Philadelphia, pp. 1811-1856.

22. Shoenfeld, Y., Udassin, R., Shapiro, Y., Ohri, A. \& Sahor, E. (1987) Age and sex difference in response to short exposure to extreme dry heat. J. Appl. Physiol. 44, 1-4.

23. Komives, G. K., Robinson, S. \& Robert, J: T. (1966) Urea transfer across the sweat glands. J. Appl. Physiol. 21, 16811684.

24. Dohm, G. L., Williams, R. T., Kasperek, G. J. \& Andre, M. V. (1982) Increased excretion of urea and N-methylhistidine by rats and humans after a bout of exercise. J. Appl. Physiol. 52, 27-33.

25. Gibinski, K., Kokot, F. \& Nowak, A. (1963) Glucose excretion in thermal sweat. Arch. Med. Wewnetrznej 11, 1249-1251.

\author{
Yassar Yahya Al-Tamer, M. Sc., Ph. D. \\ Department of Chemistry \\ College of Education \\ University of Mosul \\ Mosul \\ Iraq
}




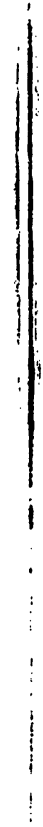

